\title{
VIDA E MORTE NO COTIDIANO DE PERSONAGENS SOLITÁRIAS E INFELIZES
}

CANDIDO, Weslei. Condominio fechado. Guaratinguetá: Penalux, 2020.112 p.

Altamir Botoso*

O conto, narrativa breve por excelência, é um gênero difícil, conforme postulam muitos escritores que se dedicaram a sua escrita. Nessa seara, aventura-se o professor universitário Weslei Roberto Candido, com o livro Condomínio fechado, uma coletânea composta de treze histórias bem construídas e que revelam talento e maestria na condução dos enredos bem urdidos e que deixam entrever aqui e acolá, o resquício das leituras efetuadas ao longo dos anos, de importantes ficcionistas nacionais e estrangeiros, que se amalgamam indelevelmente aos relatos que parecem seguir à risca o preceito de Poe da unidade de efeito. Todas as narrativas da referida obra apresentam um final que surpreende o seu leitor e o arrebata. O inesperado e o improvável unem-se e conduzem a uma experiência de leitura ímpar, inovadora e valiosa, sem sombra de dúvida.

Weslei já adentrou o campo da poesia, com Memória das palavras (2012), texto no qual se evidencia a qualidade de suas construções poéticas e "o talento na construção dos versos, na arte de manejar as palavras, transfigurando-as em frases que emocionam, impactam e seduzem o leitor" (BOTOSO, 2016, p. 3). Na área da crítica literária, publicou dois estudos de fôlego, resultado de suas pesquisas no meio acadêmico: José de Alencar. sou americano para o que der e vier (2016) e O instinto de americanidade na poesia de Fagundes V arela (1841-1875), os quais tratam da questão da americanidade na produção de dois importantes escritores do Romantismo brasileiro.

A obra que ora vem a público conta com um prefácio de Marisa Corrêa Silva, professora da Universidade Estadual de Maringá, que pontua algumas chaves interpretativas extremamente pertinentes em relação às narrativas breves de Condomínio fechado, começando com a epígrafe, Lasciate ogni speranæa, voi ch'entrate! (“Deixai toda esperança, ó vós que entrais!”), extraída da Divina Comédia, do escritor Dante Alighieri (1265-1321) e tecendo observações

\footnotetext{
* Doutor em Letras pela Universidade Estadual Paulista Júlio de Mesquita Filho (Unesp). Professor da Universidade Estadual de Mato Grosso do Sul (Uems).
} 
agudas e precisas sobre as personagens "absolutamente fechadas em si mesmas", as quais "são incapazes de ouvir o outro, escutam apenas a voz das próprias demandas, de seus pequenos caprichos ou de sua falta de alternativas - o que [a]s condena, inapelavelmente" (SILVA, 2020, p. 7).

Em consonância com o prefácio mencionado, o docente e ficcionista Whisner Fraga escreve as "orelhas" do livro de Weslei, destacando as personagens e o espaço como elementos de grande relevância na construção das histórias e que deixam evidentes um "espaço coletivo" e seres que primam pela busca de isolamento e solidão.

Inegavelmente, um elemento que já é uma marca registrada nos escritos de Weslei Candido é a intertextualidade, que se faz presente tanto nos seus textos poéticos quanto ficcionais. Nos contos, é possível vislumbrar o macabro de Edgar Allan Poe (1809-1849), temas recorrentes da poética de Jorge Luis Borges (1899-1986) como a biblioteca, o fantástico, ou ainda os mortos de Pedro Páramo, do mexicano Juan Rulfo (1917-1986), o ser monstruoso de Franz Kafka (1883-1924), as baratas de Clarice Lispector (1920-1977) que aparecem em seus contos e no romance $A$ paixão segundo $G$. $H$., além de inúmeras outras referências, alusões, confirmando a erudição e a capacidade de estabelecer diálogos profícuos de suas produções com a tradição literária ocidental.

Conforme já salientamos, a "memória da literatura" ecoa nas poesias e nos relatos ficcionais do escritor palmitalense, por intermédio de relações intertextuais bem arquitetadas e que mantêm e reavivam o diálogo perene entre as obras de todos as épocas, uma vez que

\footnotetext{
A literatura se escreve com a lembrança daquilo que é, daquilo que foi. Ela a exprime, movimentando sua memória e a inscrevendo nos textos por meio de um certo número de procedimentos de retomadas, de lembranças e de re-escrituras, cujo trabalho faz aparecer o intertexto. Ela mostra assim sua capacidade de se constituir em suma ou em biblioteca e de sugerir o imaginário que ela própria tem de si. Fazendo da intertextualidade a memória da literatura, propõe-se uma poética inseparável de uma hermenêutica: trata-se de ver e de compreender do que ela procede, sem separar esse aspecto das modalidades concretas de sua inscrição. (SAMOYAULT, 2008, p. 47)
}

Nesse sentido, podemos afirmar que a atividade escritural de Weslei está impregnada pela memória de leituras e releituras realizadas ao longo de sua vida e que se enraízam em sua escrita e possibilitam a revitalização do passado, ressaltam e deixam patentes novas interpretações, novas possibilidades de entrelaçar criações literárias do presente com o passado, nos moldes preconizados pelo poeta francês Valéry Larbeau (1946, p. 217 apud SAMOYAULT, 2008, p. 47): 
$\mathrm{O}$ fato mesmo de que isto, este verso, esta frase entre aspas venha de outro lugar, alarga o horizonte intelectual que traço em torno do leitor. É um apelo ou antes uma chamada, uma comunicação estabelecida: toda a Poesia, todo o tesouro da literatura evocados brevemente, relacionados com minha obra no pensamento daquele que a lê.

Em Condominio fechado, o leitor é desafiado a estabelecer conexões, elos entre textos de diferentes autores, distanciados ou não da nossa contemporaneidade, e também a mergulhar nas malhas das narrativas, para que exercite o seu intelecto e possa extrair os significados que se ocultam sob a aparências de histórias simples, mas que a um olhar mais aprofundado, deixam entrever os mistérios insondáveis que perpassam a alma humana.

Apostando na capacidade do leitor, Weslei Candido não é condescendente com ele, exigindo um leitor crítico, nos moldes preconizados por Machado de Assis, em Esaú e Jacó (1976, p. 128): “o leitor atento, verdadeiramente ruminante, tem quatro estômagos no cérebro, e por eles faz passar e repassar os atos e os fatos, até que deduz a verdade, que estava, ou parecia estar escondida."

Dessa maneira, o leitor passivo não encontra guarida nas páginas do livro de Weslei, pois uma vez que se aventure na leitura, será instigado a refletir sobre o que lê, será obrigado, algumas vezes, a retornar ao início, a reler o texto, para poder apreender os seus múltiplos sentidos, conforme acontece com toda obra de qualidade, que solicita um receptor que "rumine", "mastigue”, “digira” o narrado, para só então tirar as próprias conclusões.

Embora o humor não seja a tônica da obra em apreço, em alguns momentos, é possível entrever a sua presença, como acontece na segunda narrativa de Condomínio fechado, intitulada de "Humanamente divino":

Era homem de novo e como é bom ter orgulho de si mesmo. Brindei no ar a taça de vinho. Peguei o controle, sentei no sofá e repetia no canal de esportes Barcelona e Leganés. Pela manhã recolheria os corpos, por ora era bom contemplar aquele campo de pernas para o ar. Dei a elas ainda o direito à dor do luto. Sou divino. (CANDIDO, 2020, p. 24)

O protagonista, cujo nome não é mencionado, consegue livrar-se de uma invasão de diminutas baratas em seu apartamento. Todo o seu percurso até atingir a meta de se livrar das indesejadas inquilinas vem permeado de comicidade e, mais vez, pontua a habilidade do autor do livro de promover a reflexão sobre uma questão banal, mas que desvela um universo mediano, sem grandes perspectivas, e revelador do apego a tarefas corriqueiras para escapar do tédio e de uma vida vazia e sem possibilidades de mudanças.

O espaço, que já se encontra ressaltado no título da coletânea, apesar de enfatizar o coletivo por meio de reuniões, de contatos superficiais no elevador, ou nos corredores do 
prédio, é caracterizado pelo sintagma "fechado", o que acaba por dar relevância ao mundo das personagens, que são "fechadas", vivem isoladas em seus apartamentos e, mesmo aquelas que têm famílias, pouco dialogam entre si, formando pequenas ilhas indevassáveis, nas quais os desejos, as perversões, as taras só podem manifestar-se no isolamento, na penumbra de janelas que permanecem cerradas e onde raramente a luz pode penetrar.

Essas histórias, que mesclam a mediocridade, a infelicidade, a morbidez, o inexplicável, mas também as pequenas alegrias de um “matador de baratas", momentos de prazer (solitário ou na companhia de uma esposa indiferente ou mesmo impaciente), desvelam a humanidade de seres que se tornaram incapazes de modificar a sua existência, e nem desejam isso. São símbolos do fracasso, da perda paulatina de objetivos concretos, da consciência de que tudo está fadado a apodrecer, a morrer, inexoravelmente.

Embora perpassados por um pessimismo nietzschiano e até schopenhaueriano, a leitura dos contos é extremamente agradável e permite um mergulho no cotidiano de personagens que parecem ter saído da realidade que nos cerca: homens, mulheres, velhos e velhas, vizinhos que se arrastam na modorra dos dias e que esperam, pacientemente, ansiosamente, na maioria das vezes, o momento de sair de cena.

\section{REFERÊNCIAS}

ASSIS, Machado de. Esaú e Jacó. 4. ed. São Paulo: Cultrix, 1976.

BOTOSO, Altamir. O cotidiano em imagens poéticas: notas sobre o livro Memória das palavras de Weslei Roberto Candido. Resenha. Revista InterteXto, v. 9, n. 2, 2016, p. 1-4. Disponível em: http://seer.uftm.edu.br/revistaeletronica/index.php/intertexto/article/view/ 1894/2072. Acesso em: 24 dez. 2020.

SAMOYAULT, Tiphaine. A intertextualidade. Tradução de Sandra Nitrini. São Paulo: Aderaldo \& Rothschild, 2008.

SILVA, Marisa Corrêa. Prefácio. In: CANDIDO, Weslei. Condominio fechado. Guaratinguetá: Penalux, 2020, p. 7-10.

Recebido em: 25/12/2020.

Aprovado em: 26/01/2021. 